КАРИМОВА Регина Мажитовна - кандидат социологических наук, научный сотрудник Государственного автономного учреждения Центр гуманитарных наук Министерства культуры Республики Башкортостан (2. Уфа, Россия, 450076, mreginam@mail.ru)

ХАМАТДИНОВ Руслан Ильдарович - социолог-аналитик научный сотрудник Государственного автономного учреждения Центр гуманитарных наук Министерства культуры Республики Башкортостан (2. Уфа, Россия, 450076)

ЮСУПОВ Ильшат Фаритович - кандидат социологических наук, научный сотрудник Государственного автономного научного учреждения Институт стратегических исследований Республики Башкортостан (г Уфа, Россия, 450050, ilshat_iosopov@mail.ru)

\title{
ГРАЖДАНСКАЯ И ЭТНИЧЕСКАЯ ИДЕНТИЧНОСТЬ НАСЕЛЕНИЯ РЕСПУБЛИКИ БАШКОРТОСТАН: УРОВНИ, ИНТЕНСИВНОСТЬ И ФАКТОРЫ
}

\begin{abstract}
Аннотация. В статье показана значимость развития гражданской идентичности населения в Российской Федерации с целью формирования общероссийской гражданской политической нации при одновременном этнокультурном развитии народов, населяющих нашу страну. Приводятся результаты исследования общегражданской, региональной и этнической идентичности населения Республики Башкортостан, их соотношение, а также возможность позитивной совместимости. Показано, что интенсивность групповой идентичности населения определяется такими факторами как степень урбанизированности, уровень образования, возраст, этническая принадлежность.

Ключевые слова: групповая идентичность, общегражданская идентичность, этническая идентичность, факторы идентичности, солидарность, этнокультурное развитие
\end{abstract}

$\mathrm{P}$ еспублика Башкортостан активно участвует в реализации «Стратегии государственной национальной политики Российской Федерации на период до 2025 года» и федеральной программы «Укрепление единства российской нации и этнокультурное развитие народов России». Перед органами государственной власти Башкортостана стоит основная задача - поддержания баланса между процессами межэтнической интеграции, укрепления общегражданской идентичности и сохранения национально-культурной самобытности народов республики.

Социологический анализ идентичности актуален для диагностики положительных и отрицательных тенденций, профилактики развития межэтнических конфликтов, ксенофобии и экстремизма. Распространенность групповой идентичности среди населения, ее содержание (гражданское, государственническое, этническое), характер (его позитивная или негативная направленность) говорят и о целостности государства с точки зрения восприятия его гражданами страны, и об уровне согласия в обществе [Дробижева 2014].

У понятия гражданская идентификация отсутствует единое определение. Причины неполного понимания содержания гражданской идентичности Л.М. Дробижева видит в недостаточной научной разработанности темы и ее трансляции в СМИ и сфере образования [Дробижева 2017]. По мнению Л.М. Дробижевой, государственно-гражданская идентичность подразумевает самоотождествление с общностью в масштабах страны, «образ мы» и интересы. «Образ мы» в данном случае включает, кроме представлений об общей истории, языке, территории, представления о месте страны в мире. При этом подразумевается не просто лояльность к государству, но и представления о 
сообществе граждан государства, их ценностях и ориентациях, ответственность за судьбу страны и переживаемые в связи с этим чувства. Так же, как и в республиканской, локальной, этнической идентичности здесь присутствуют когнитивные, эмоциональные и регулятивные элементы (готовность к действию во имя этих представлений и переживаний) Этническая идентичность включает в себя самоотождествление с этнической группой, представление о своей группе («образ мы»), о языке, культуре, истории этнической группы, территории ее проживания, истории, а также общие интересы группы.

Во многих работах государственно-гражданская идентичность исследуется в сравнении и соотношении именно с региональными и этническими идентичностями, как противостоящими, способствующими росту сепаратизма территорий. А.А. Алаутдинов дает определение региональной идентичности - «сложносоставной и комплексный общественно-политический феномен, представляющий собой, во-первых, процесс восприятия индивидами себя вследствие интереоризации и категоризации соответствующего социального пространства в качестве носителей преемственности местных общностей и членов регионального сообщества, а во-вторых, результат самоопределения и самосознания данной региональной общности на ментальном, историческом, социокультурном, экономическом, политическом и т. д. уровнях» [Алаутдинов 2012: 188].

Л. В. Клименко отмечает, что в регионах, отличающихся сложной этнической и конфессиональной структурой, региональная идентичность выполняет функцию усиления гражданственной идентичности по отношению к этноконфессиональной и локально-территориальной [Клименко 2011].

Л. М. Дробижева делает акцент на вопросе позитивной совместимости национально-гражданской и этнической идентичности. В гражданской идентичности заложен ресурс позитивной интеграции общества, без которой не могут складываться политические нации [Дробижева 2017]. В. А. Тишков подчеркивает, что «формула российской идентичности вовсе не отрицает наличие наций. Это не нужно трактовать так, что мы жестко лепим из всех одну большую нацию. Речь идет о сложной формуле самоидентификации», указывая на то, что теперь предстоит наполнить содержанием то самое «российское самосознание». Теперь, по его мнению, главная задача - формирование «общероссийской гражданской политической нации при одновременном этнокультурном развитии народов, населяющих нашу страну» 1 . По мнению А. А. Алаутдинова, формирование общенациональной идентичности в современной России может быть успешным только в том случае, если она будет рассматриваться не как отдельный абстрактный конструкт, а как композиция конкретного целого. Сложность единства - это та идея, которая должна лежать в основе формирования общенациональной политической идентичности современной России на базе синтеза различных региональных идентичностей, существующих внутри страны [Алаутдинов 2012].

Изучение социальных аспектов этнической идентификации имеет большое значение для выработки оптимальной национальной политики и ее реализации. Научно-обоснованная национальная политика в сочетании с устойчивым ростом экономики, укреплением демократических порядков в каждом регионе

\footnotetext{
${ }^{1}$ Колебакина-Усманова Е. Валерий Тишков: «Не нужно трактовать, что мы жестко лепим из всех одну большую нацию» // Доступ: http://samtatnews.ru/2019/11/21/\%D0\%B2\%D 0\%B0\% D0\%BB\%D0\%B5\%D1\%80\%D0\%B8\%D0\%B9-\%D1\%82\%D0\%B8\% D1\%88\%D0\%BA $\% \mathrm{D} 0 \% \mathrm{BE} \% \mathrm{D} 0 \% \mathrm{~B} 2-\% \mathrm{D} 0 \% \mathrm{BD} \% \mathrm{D} 0 \% \mathrm{~B} 5-\% \mathrm{D} 0 \% \mathrm{BD} \% \mathrm{D} 1 \% 83 \% \mathrm{D} 0 \% \mathrm{~B} 6 \% \mathrm{D} 0 \% \mathrm{BD} \% \mathrm{D} 0 \% \mathrm{BE}-$ $\% \mathrm{D} 1 \% 82 \% \mathrm{D} 1 \% 80 \% \mathrm{D} 0 \% \mathrm{~B} 0 \% \mathrm{D} 0 \% \mathrm{BA} \% \mathrm{D} 1 \% 82 \% \mathrm{D} 0 \% \mathrm{BE} \% \mathrm{D} 0 \% \mathrm{~B} 2 \% \mathrm{D} 0 \% \mathrm{~B} 0 \% \mathrm{D} 1 \% 82 \% \mathrm{D} 1 \%$ 8C-\% D1\%87/ (дата обращения 22.11.2019).
} 
страны дает возможность избежать межэтнических конфликтов и гармонизировать этнические отношения. Используя методику Л. М. Дробижевой, мы попытаемся определить, как совмещаются государственно-гражданская, региональная и этническая идентичности.

Специалисты отмечают многоуровневый характер идентичности. В зависимости от конкретно-исторической ситуации может произойти актуализация любого из идентификационных оснований или же возникнуть их новая комбинация. Структура идентичности динамична и меняется в зависимости от изменений веса составляющих ее элементов [Жаде 2007]. Важно отметить, что интенсивность этнической идентичности детерминирована различными факторами. В качестве факторов, снижающих интенсивность этнической идентификации, ослабляющих действие этнического поля, исследователи называют урбанизацию с характерной для нее трансформацией коммуникативных процессов. Множество интеракций приводят к «психологической индифферентности» между людьми в обществе, этническая идентичность подавляется искусственными и квазиэтническими идентичностями. Есть и другая точка зрения, отрицающая мнение, согласно которому города являются «кладбищами наций» и неизбежно нивелируют этничность своих граждан. Напротив, урбанизированные этносы, успешно прошедшие этап адаптации к городскому образу жизни, оказались как в культурном, так и в социальном отношении более развитыми, адаптивными и жизнеспособными, нежели народы, отказавшиеся изменить свой традиционный образ жизни.

В качестве второго фактора, снижающего интенсивность этнической идентификации, называют повышение уровня грамотности и доли лиц с высшим образованием. Согласно этой позиции, люди с высшим образованием менее подвержены воздействию этнического поля, и в их системе идентичностей преобладают искусственные идентичности на политической, экономической, социальной или культурной основе. Исследователи подчеркивают, что в условиях системного кризиса данные процессы усиливаются [Пузько 2007]. По мнению Т. Г. Стефаненко, на осознание людьми своей этнической принадлежности оказывает влияние то обстоятельство, живут ли они в полиэтнической или моноэтнической среде. Опыт межэтнического общения дает больше возможностей для приобретения знаний об особенностях своей и других этнических групп, способствует развитию межэтнического понимания и формированию коммуникативных навыков. Отсутствие опыта обусловливает, с одной стороны, меньшую предрасположенность к подобным контактам, а с другой стороны - меньший интерес к собственной идентичности [Стефаненко 2000].

Социально-экономическая и политическая ситуация может способствовать позитивным трендам в сочетании национально-гражданской и этнической идентичности. Развитая гражданская идентичность, диалоговый режим, а не просто солидарность с соотечественниками формируется на основе доверия к власти. Результаты нашего исследования подтверждают данный тезис. Аналогичная ситуация с региональной и локальной идентичностью. Кроме того, отмечено, что респонденты с актуализированной национально-гражданской идентичностью более открыты для общения и взаимодействия, им реже свойственны этнические предрассудки и «этническая замкнутость». Показателем данных аттитюдов является ответ на вопрос о неприязненном отношении к лицам иной этнической принадлежности. Так, участники опроса, ответившие, что они не испытывают этнические предрассудки, чаще ощущают близость с жителями России, чем те, кто таких предубеждений не имеет.

Эта закономерность свойственна также региональному и муниципальному уровням идентичности. Респонденты, ответившие, что они испытывают этни- 
ческие предрассудки чаще испытывают близость с жителями республики, чем те, кто таких предубеждений не имеет. Респонденты, ответившие, что они не испытывают этнические предрассудки чаще испытывают близость с жителями своего города или села, чем те, кто имеет такие предубеждения.

Нам представляется, что полученные результаты подтверждают, что проблема позитивного совмещения гражданской и этнической идентичности связана с проблемой этноизоляционистских предубеждений. По мнению исследователей, в силу того, что Республика Башкортостан является одним из самых полиэтничных регионов России, актуализация социальной идентичности происходит в условиях противопоставления «мы» - «они». Именно поэтому в многонациональных регионах этническая идентичность выражена, как правило, сильнее, чем в мононациональных [Шайхисламов, Садретдинова, Коровкина 2016]. Помимо колебаний интенсивности этнической идентичности авторы указывают на возможность управления процессом этнизации [Федоров, Филюшкин 2016]. Вместе с тем формирование гражданской и этнической идентичности может быть успешным лишь в том случае, если они опираются на какие-то исторически сложившиеся представления. При этом «конструкция конструктов» (по Р. Брубейкеру) формируется с учетом настроения масс [Брубейкер 2012]. В данной работе формирование этнической идентичности не рассматривается на идеологическом уровне (через дискурс элит). Авторов интересует исследование представлений людей на основе массовых опросов.

Основной показатель общегражданской идентичности измеряется по методике ФАДН как сумма ответов «часто» и «иногда» на вопрос «Как часто Вы ощущаете близость со всеми гражданами России, с теми, о ком Вы могли бы сказать: «Это - мы»?». Согласно данным опроса, поведенного ЦГИ в 2020 г., показатель составил 78,9 \%. Причем в 2017 г. этот показатель составил 70,6 \%. Более 82,1 \% жителей Республики Башкортостан ощущают духовную близость с гражданами России.

Таблица 1

Распределение ответов на вопрос «Как часто Вы ощущаете близость с разными группами людей - с теми, о ком Вы могли бы сказать: «Это - мы»?» (сумма ответов «часто» и «иногда»), в \% к опрошенным

\begin{tabular}{|l|c|c|}
\hline \multirow{2}{*}{ Ощущение связи, единства } & \multicolumn{2}{|c|}{ Период, гг. } \\
\cline { 2 - 3 } & $\mathbf{2 0 1 7}$ & $\mathbf{2 0 2 0}$ \\
\hline С людьми Вашего поколения & 89,5 & 89,3 \\
\hline С людьми той же профессии, рода занятий & 86,0 & 87,3 \\
\hline Со всеми гражданами России & 70,6 & 78,9 \\
\hline С жителями края, республики, области & 80,4 & 82,1 \\
\hline С теми, кто живет в том же городе, селе & 86,0 & 88,1 \\
\hline С людьми Вашей национальности & 86,2 & 88,9 \\
\hline С людьми того же достатка, что и Вы & 80,8 & 84,7 \\
\hline С людьми, близкими Вам по политическим взглядам & 69,7 & 80,3 \\
\hline С людьми Вашей веры & 73,7 & 84,1 \\
\hline
\end{tabular}

Анализ структуры идентификации показывает, что в ней доминируют группы повседневного общения, что обоснованно озабоченностью людей проблемами 
повседневной жизни и материальными заботами. Наилучшее взаимопонимание, общий язык опрошенные находят с людьми одного с ними поколения, возраста (89,3\% респондентов), одной национальности $-88,9 \%$, с теми, кто живет в том же городе, селе - 88, $1 \%$, с людьми того же достатка $-84,7 \%$, схожей профессии, рода занятий $-87,3 \%$, той же веры - 84,1 \%. Далее по значимости выносится республиканская принадлежность $(82,1 \%)$. Уже после неё по значимости респонденты склонны отождествлять себя с гражданами России $(78,9 \%)$.

Если ранее исследователи отмечали снижение роли этничности в повседневной жизни населения республики, то сейчас мы наблюдаем, что она занимает лидирующие позиции как в повседневной жизни (сверстники, профессия), так и в системе этнополитических категорий, опережая гражданскую и республиканскую идентичность (88,9 \% против 78,9 \% и 82,1 \% соответственно). Специалисты отмечают высокий уровень этнической идентичности в республиках с доминирующим нерусским населением [Глебов, Исаев 2018].

Рассмотрим значимость различных видов идентификации в этническом разрезе. Чаще других этносов близость с гражданами России отмечают башкиры (сумма ответов «часто» и «иногда» $82,9 \%$ ), русские $(74,9 \%)$. Аналогично тому, как у башкир сильнее, чем у других этносов выражена региональная идентичность $(88,2$ \% сумма ответов «часто» и «иногда» на вопрос о том, как часто они ощущают духовную близость с жителями республики, края, области, где они живут»), в наименьшей степени - у русских (77 \%). Этот вид идентичности у русских актуализирован, но в меньшей мере, чем у респондентов других национальностей, поскольку этническая идентичность у них замещается общероссийской. Ряд этнополитологов (В.А. Тишков, Э.А. Паин) считают, что активизация солидаризации русских - это ответ на вызовы этнонационализма в республиках 90-ых годов и быстрый массовый приток инонациональных мигрантов [Дробижева 2012: 9].

Кроме того, у башкир и татар больше развита локальная идентичность, т.е. чувство духовной близости с теми, кто живет в том же городе (селе), что и они (91,4 и 91,1\% соответственно), по сравнению с русскими $(82,3 \%)$.

При рассмотрении дифференциации ответов в возрастных группах можно отметить, что респонденты старшего возраста демонстрируют большую этническую идентичность. Существуют связь между возрастом и этнической идентичностью, которая проявилась в различных возрастных группах. В исследовании С.Д. Гуриевой показано, что есть определенные возрастные периоды, когда этническая принадлежность попадает в сферу «осознанной и важной», является наиболее значимой для человека [Гуриева 2000].

На наш взгляд, более низкая гражданская, региональная и этническая идентификация молодежи обусловлена тем, что жизнедеятельность связана с реализацией в учебе, профессиональной деятельности, брачно-семейных отношений и приоритетом личных интересов. Молодые люди еще не целиком задействованы в жизни социума, а только начинают освоение новых его сфер, воспринимая себя скорее, как автономных субъектов.

В ходе анализа распределения ответов в образовательном разрезе мы наблюдаем обратную зависимость: чем выше уровень образования, тем ниже значимость идентичностей для респондента. 
Таблииа 2

Распределение ответов на вопрос «Как часто Вы ощущаете близость с разными группами людей - с теми, о ком Вы могли бы сказать: «Это - мы»?» (ответ «часто») в зависимости от возраста, в \% к опрошенным

\begin{tabular}{|c|c|c|c|c|c|c|}
\hline \multirow[b]{2}{*}{ Ощущение связи, единства } & \multicolumn{6}{|c|}{ Возрастные группы } \\
\hline & $\begin{array}{l}\stackrel{J}{N} \\
1 \\
\infty \\
\infty\end{array}$ & $\begin{array}{l}\text { ले } \\
1 \\
\text { స్ }\end{array}$ & $\frac{P}{\frac{1}{m}}$ & $\begin{array}{l}\stackrel{8}{7} \\
\frac{1}{7}\end{array}$ & $\begin{array}{l}8 \\
\frac{1}{6}\end{array}$ & 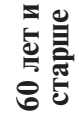 \\
\hline С людьми той же профессии, рода занятий & 50,5 & 53,8 & 65,9 & 63,7 & 73,7 & 75,1 \\
\hline Со всеми гражданами России & 26,9 & 28,8 & 29,1 & 37,7 & 59,8 & 60,7 \\
\hline С жителями края, республики, области & 28,8 & 29,8 & 45,1 & 44,6 & 64,8 & 70,5 \\
\hline С теми, кто живет в том же городе, селе & 40,9 & 40,9 & 58,8 & 56,9 & 74,3 & 81,5 \\
\hline С людьми того же достатка, что и Вы & 33,7 & 40,9 & 58,8 & 61,3 & 70,9 & 79,2 \\
\hline С людьми Вашей национальности & 42,3 & 46,6 & 61,0 & 62,7 & 77,1 & 80,3 \\
\hline $\begin{array}{l}\text { С людьми, близкими Вам по политическим } \\
\text { взглядам }\end{array}$ & 46,6 & 39,9 & 40,1 & 53,9 & 69,8 & 69,4 \\
\hline С людьми Вашей веры & 44,2 & 45,2 & 54,4 & 61,8 & 77,1 & 79,2 \\
\hline
\end{tabular}

Таблица 3

Распределение ответов на вопрос «Как часто Вы ощущаете близость с разными группами людей - с теми, о ком Вы могли бы сказать: «Это - мы»?» (ответ «часто») в зависимости от образования, в \% к опрошенным

\begin{tabular}{|l|c|c|c|c|}
\hline \multirow{2}{*}{ Ощущение связи единства } & \multicolumn{4}{|c|}{ Уровень образования } \\
\cline { 2 - 5 } & $\begin{array}{c}\text { Среднее общее } \\
\text { (школа) 11 } \\
\text { классов и ниже }\end{array}$ & $\begin{array}{c}\text { Начальное } \\
\text { проф. (проф. } \\
\text { училище) }\end{array}$ & $\begin{array}{c}\text { Среднее проф. } \\
\text { (техникум, } \\
\text { колледж) }\end{array}$ & $\begin{array}{c}\text { Высшее } \\
\text { образование } \\
\text { (незаконченное } \\
\text { высшее) }\end{array}$ \\
\hline $\begin{array}{l}\text { Со всеми гражданами } \\
\text { России }\end{array}$ & 45,1 & 47,4 & 42,6 & 30,8 \\
\hline $\begin{array}{l}\text { С жителями края, } \\
\text { республики, области }\end{array}$ & 54,9 & 56,4 & 47,3 & 37,1 \\
\hline $\begin{array}{l}\text { С теми, кто живет в том } \\
\text { же городе, селе }\end{array}$ & 64,7 & 66,7 & 61,3 & 47,0 \\
\hline $\begin{array}{l}\text { С людьми Вашей } \\
\text { национальности }\end{array}$ & 62,1 & 70,5 & 66,0 & 50,8 \\
\hline С людьми Вашей веры & 66,1 & 67,9 & 61,7 & 50,5 \\
\hline
\end{tabular}

При сравнении идентичности в зависимости от места жительства респондента выявлено, что отсутствуют значительные различия в уровне государственно-гражданской и республиканской идентичности. Наиболее заметные различия наблюдаются в локальной и этнической идентичности.

Менее урбанизированные территории характеризуются более тесными кон- 
тактами и взаимосвязями, высоким уровнем идентичности, острее ощущают поликультурность среды.

Таблица 4

Распределение ответов на вопрос «Как часто Вы ощущаете близость с разными группами людей - с теми, о ком Вы могли бы сказать: «Это - мы»?» (ответ «часто») в зависимости от места жительства, в \% к опрошенным

\begin{tabular}{|l|c|c|c|}
\hline \multirow{2}{*}{\multicolumn{1}{|c|}{ Ощущение связи, единства }} & \multicolumn{3}{|c|}{ Место жительства } \\
\cline { 2 - 4 } & $\begin{array}{c}\text { Город } \\
\text { (кроме Уфы) }\end{array}$ & Село & Уфа \\
\hline Со всеми гражданами России & 41,7 & 38,5 & 38,9 \\
\hline С жителями края, республики, области & 46,8 & 46,8 & 44,6 \\
\hline С теми, кто живет в том же городе, селе & 55,5 & 66,4 & 48,4 \\
\hline С людьми Вашей национальности & 56,2 & 69,4 & 54,1 \\
\hline С людьми Вашей веры & 60,8 & 60,2 & 56,7 \\
\hline
\end{tabular}

Необходимо отметить, что особенность применения методики в вышеуказанном вопросе заключалась в том, что по всем видам идентификаций задавался отдельный вопрос, а не перечень вариантов ответов, которые можно сопоставить и выбрать наиболее соответствующий представлениям респондента. При этом в следующем вопросе «Кем Вы себя чувствуете в большей мере?» варианты ответов государственно-гражданской и региональной идентичности были приведены в одном вопросе.

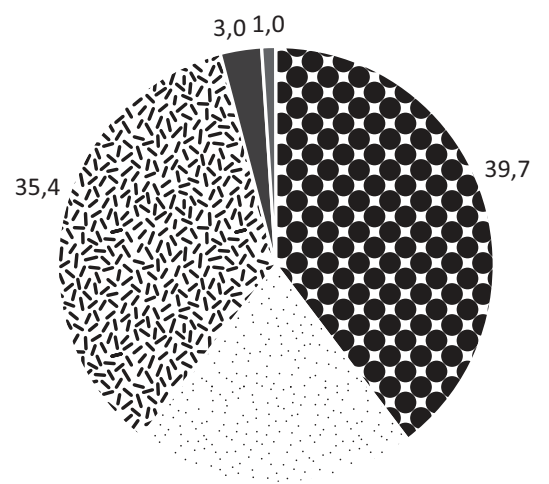

20,9

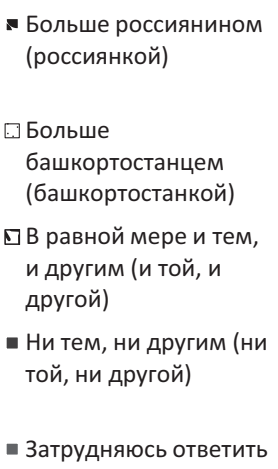

- Затрудняюсь ответить

\section{Рисунок 1. Мнение респондентов об их самоидентификации, \%}

Полученные данные показали преобладание гражданской и совмещенной идентичности (гражданской и региональной) над региональной. При ответе на вопрос «Кем Вы себя чувствуете в большей мере?» каждый пятый респондент $(20,9 \%)$ назвал себя больше башкортостанцем, $39,7 \%$ - больше россиянином и $(35,4 \%)$ - в равной мере россиянином и жителем республики, $3 \%$ отвергли обе идентичности, $1 \%$ затруднились ответить. 
Гражданская самоидентификация во многом детерминирована этнической принадлежностью. Так, среди русских значительно большая, по сравнению с другими этносами, доля тех, кто относит себя к россиянам $(61,5 \%)$, башкиры - чаще, чем другие, называют себя больше башкортостанцами $(39,3 \%)$, татары - в равной мере и теми и другими (44,9\%). Среди миноритарных по численности этносов самая большая доля тех, кто не относит себя ни к россиянам, ни к башкортостанцам $(11,7 \%)$.

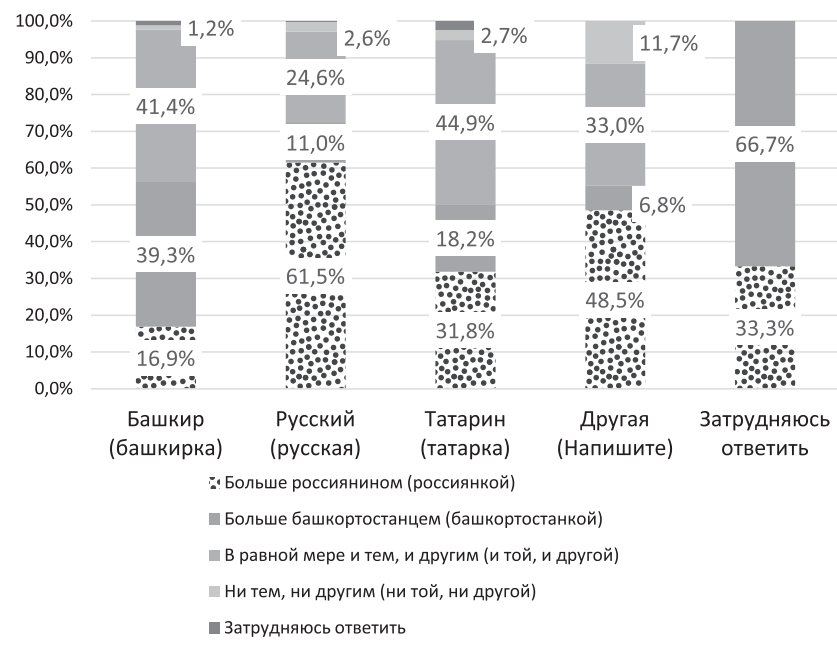

Рисунок 2. Мнение респондентов об их самоидентификации в зависимости от национальности, \%

При рассмотрении ответов в разрезе других социально-демографических групп значительно интенсивнее государственная идентичность появляется у молодежи, чем у более старших возрастных групп. Это связано с большей открытостью границ, повышенной мобильностью личности и социальных групп, интенсификацией и диверсификацией информационных потоков, ускорением и усложнением межкультурного обмена, а также с другими последствиями глобализации, затрудняющих процессы индивидуальной и коллективной самоидентификации. И, напротив, региональная идентичность чаще встречается у респондентов более старшего возраста.

Таблица 5

Распределение ответов на вопрос «Кем Вы себя чувствуете в болышей мере?» в зависимости от возраста, в \% к ответившим

\begin{tabular}{|l|c|c|c|c|c|c|}
\hline \multirow{2}{*}{\multicolumn{1}{|c|}{ Идентификация }} & \multicolumn{7}{|c|}{ Возрастные группы } \\
\cline { 2 - 8 } & $\begin{array}{c}\mathbf{1 8 - 2 4} \\
\text { года }\end{array}$ & $\begin{array}{c}\mathbf{2 5 - 3 0} \\
\text { лет }\end{array}$ & $\begin{array}{c}\mathbf{3 1 - 4 0} \\
\text { лет }\end{array}$ & $\begin{array}{c}\mathbf{4 1 - 5 0} \\
\text { лет }\end{array}$ & $\begin{array}{c}\mathbf{5 1 - 6 0} \\
\text { лет }\end{array}$ & $\begin{array}{c}\mathbf{6 0} \text { лет } \\
\text { и старше }\end{array}$ \\
\hline Больше россиянином & 48,1 & 36,5 & 41,2 & 36,3 & 39,1 & 36,4 \\
\hline Больше башкортостанцем & 19,7 & 20,7 & 19,8 & 20,1 & 22,9 & 22,5 \\
\hline В равной мере и тем, и другим & 27,9 & 38,5 & 32,4 & 37,7 & 35,2 & 41,0 \\
\hline Ни тем, ни другим & 4,3 & 3,8 & 3,3 & 4,9 & 1,1 & - \\
\hline
\end{tabular}




\begin{tabular}{|l|c|c|c|c|c|c|}
\hline Затрудняюсь ответить & - & 0,5 & 3,3 & 1,0 & 1,7 & - \\
\hline Всего & 100 & 100 & 100 & 100 & 100 & 100 \\
\hline
\end{tabular}

Аналогично тому, как жители городов называют себя россиянами чаще, чем сельчане $(47,3$ \% против 32,7 \%). При этом жители сел интенсивнее идентифицируют себя с башкортостанцами, чем уфимцы (30,9\% против $14 \%$ соответственно).

Для оценки соотнесения гражданской и этнической идентичности в опросе 2020 г. был задан вопрос о том, кем больше чувствуют респонденты - россиянином или человеком своей национальности. При анализе ответов на вопрос, кем респонденты чувствуют себя в большей мере, также наблюдается преобладание гражданской идентичности над этнической: 37,1 \% считают себя скорее россиянином(кой), скорее человеком своей национальности $-22,1 \%$, и тем, и другим в равной мере $-22,4 \%$.
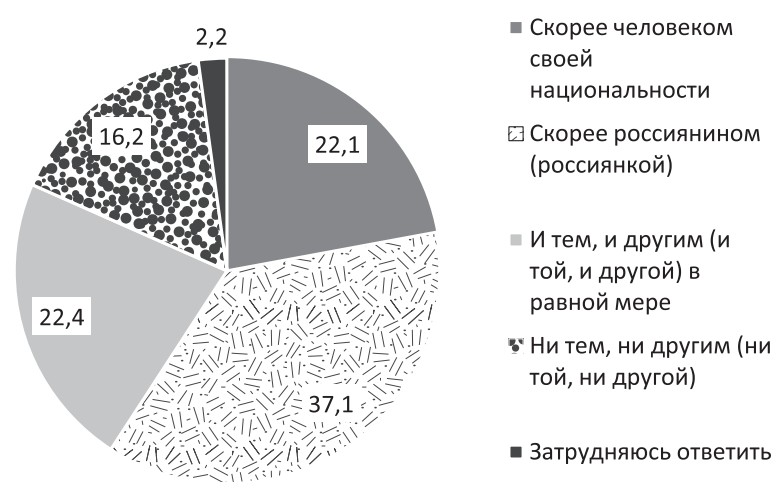

- Затрудняюсь ответить

Рисунок 3. Распределение ответов на вопрос «Кем Вы себя чувствуете в большей мере?», \%

У башкир, по сравнению с представителями других этнических групп, больше выражена этническая идентичность. Так, треть представителей титульной нации $(33,1 \%)$ считают себя «скорее человеком своей национальности», $16,9 \%$ - «скорее россиянином». При этом результаты опроса подтверждают, что у русских в большей мере, чем у других этносов развита гражданская идентичность: половина русских $(53,1 \%)$ считают, себя «скорее россиянином», и только 17,9 \% «человеком своей национальности». У татар выражена смешанная идентичность (доли тех, кто идентифицирует себя с гражданами России и представителями своей национальности 31,2 \% и 20,9\% соответственно), 25 $\%$ - россиянами и представителями своего этноса. Необходимо отметить, что у «других» этносов, не входящих в состав этих трех наиболее крупных этнических сообществ Бащкортостана, гражданская идентичность выражена больше, чем этническая.

В исследовании 2011 г. Института социально-политических и правовых исследований Академии наук Республики Башкортостан показано, что при сравнении результатов общероссийского и республиканского опросов было выявлено, что у русских в Башкортостане по сравнению с русскими в целом по России этническая идентификация существенно уступает общегражданской 


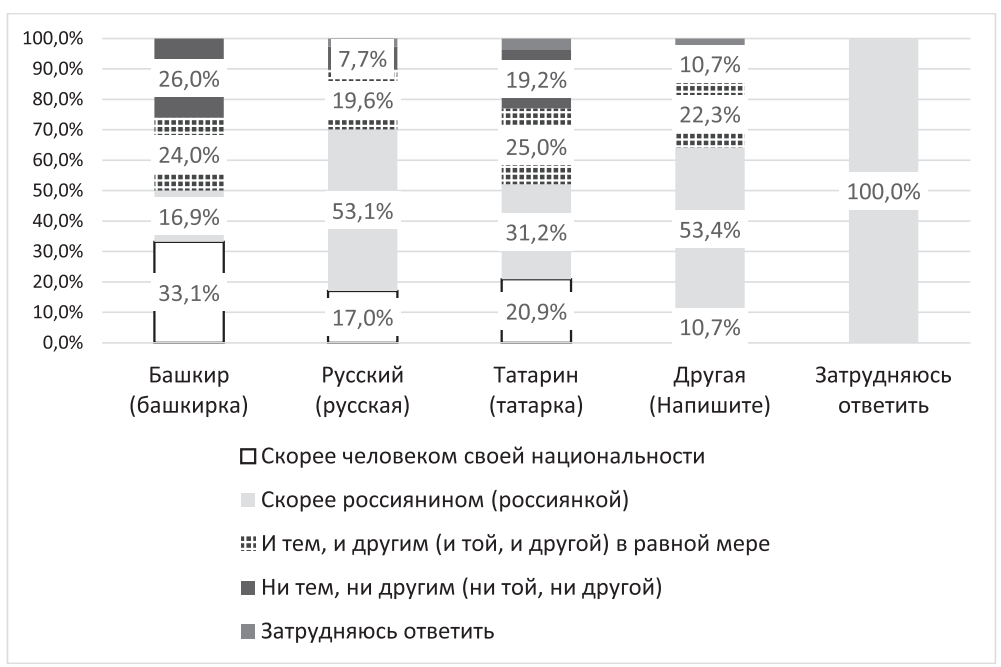

Рисунок 4. Распределение ответов на вопрос о самоидентификации в зависимости от национальности

[Леготин 2012: 41]. Это отличает русских в республике не только от башкир и татар, среди которых степень проявления этнической идентификации заметно выше, но и от русских в целом по России. В отличие от последних, русские в республике более склонны считать себя россиянами, или же представителями своей национальности и россиянами в равной степени 1 .

Можно отметить, что общегражданская и региональная идентичность широко распространена среди населения. Вместе с тем, исследование показало, что этничность безусловно занимает значимое место в структуре идентичностей населения республики.

Статья публикуется при поддержке Школы молодого этнополитолога в Республике Башкортостан (грант Фонда президентских грантов 19-2-022447).

\section{Список литературы:}

Алаутдинов А.А. 2012. Региональная идентичность как основа формирования общенациональной политической идентичности: Диссер. канд.полит. наук. М. С.188.

Брубейкер Р. Этничность без групп. М. 2012. Этничность без групп [Текст] / пер. с англ. И. Борисовой; Нац. исслед. ун-т «Высшая школа экономики». М.: Изд. дом Высшей школы экономики. 408 с.

Глебов В.В., Исаев К.В. 2018. Становление идентичности учащейся молодёжи на современном этапе развития (на примере студентов РУДН). - Мир науки, культуры, образования. № 1 (68). С. 218-219.

Гуриева С.Д. 2000. Психология межэтнических отношений: автореферат дис-

1 Социологическое исследование «20 лет реформ глазами россиян» проведено в 2011 г. Институтом социологии РАН и аналогичное исследование по идентичным инструментарию и выборочным процедурам было осуществлено и в Башкортостане Институтом социально-политических и правовых исследований Академии наук РБ. 
сертации на соискание ученой степени доктора психологических наук. СПб. $47 \mathrm{c}$.

Дробижева Л.М. 2017. Динамика гражданской идентичности и ее ресурс в позитивных интеграционных процессах российского общества. - Мониторинг общественного мнения: Экономические и социальные перемены. № 4. С. 7-22.

Дробижева Л.М. 2012. Этничность в современном социально-политическом пространстве России// Социологический ответ на «национальный вопрос»: пример Республики Башкортостан [Электронный ресурс]. М.: Институт социологии РАН. 124 с. С. 9. Официальный сайт Института социологии РАН, Доступ: http://www.isras.ru/ inab_2012_05.html. (дата обращения 23.07.2020).

Дробижева Л.М. 2014. Этническая солидарность, гражданская консолидация и перспективы межэтнического согласия в Российской Федерации//OHC. № 1.C.119-129.Доступ:http://ecsocman.hse.ru/data/2015/11/28/1250991331/119129(Drobiheva).pdf (дата обращения 23.07.2020).

Жаде 3.А. 2007. Феномен многоуровневой идентичности: цивилизационная составляющая. - Известия ВУЗов. Северо-кавказский регион. Общественные науки. №5. С. 19-23.

Клименко Л.В. 2011. Идентичность населения Республики Адыгея: соотношение общероссийского, регионального и этнического компонентов. - Социс. №1. С. $148-159$.

Леготин Э.В. 2012. Множественная идентичность в Башкортостане: этническое, региональное и общероссийское измерения // Социологический ответ на «национальный вопрос»: пример Республики Башкортостан [Электронный pecypc]. М.: Институт социологии РАН. 124 с. С. 40. Официальный сайт Института социологии РАН, Доступ: http://www.isras.ru/ inab_2012_05.html. (дата обращения 23.07.2020).

Пузько В. И. 2007. Кризис идентичности личности в условиях глобализации. - Философия и общество. №. 4 (48). С. 98-114

Стефаненко Т.Г. 2000. Этнопсихология. М: ИП РАН, Академический проект; Екатеринбург. 320 с. С. 25. С. 221.

Федоров С.Е., Филюшкин А.И. История и теория наций и национализма: учебник. - СПб.: Изд-во С.- Петерб. ун-та, 2016. - 208 с.

Шайхисламов Р.Б., Садретдинова Э.В., Коровкина Н.В. 2016. Социокультурные основания российской идентичности в региональном измерении. - Казанский социально-гуманитарный вестник. № 5 (22). С. 72-76. 
KARIMOVA Regina Mazhitovna, Cand.Sci. (Soc.), Researcher of the Center for the Humanities of the Ministry of Culture of the Republic of Bashkortostan (bld.1, 13 Gafuri St., Ufa, 450076, Russia; mreginam@mail.ru)

KHAMATDINOV Ruslan II'darovich, Sociologist-analyst, Researcher at the Center for Humanitarian Studies of the Ministry of Culture of the Republic of Bashkortostan (13/1 M. Gafuri st., Ufa, 450076, Russia)

YUSUPOV II'shat Faritovich - Cand.Sci. (Soc.), Researcher at the Center for Socio-Cultural Analysis, Institute for Strategic Studies of the Republic of Bashkortostan. (15 Kirova st., Ufa, 450008, Russia, ilshat_iosopov@mail.ru)

\title{
CIVIL AND ETHNIC IDENTITY OF THE POPULATION OF THE REPUBLIC OF BASHKORTOSTAN: LEVELS, INTENSITY AND FACTORS
}

\begin{abstract}
The article shows the importance of the development of civic identity of the population in the Russian Federation in order to form an all-Russian civic political nation with the simultaneous ethnocultural development of the peoples inhabiting our country. The results of a study of the general civil, regional and ethnic identity of the population of the Republic of Bashkortostan, their correlation, as well as the possibility of positive compatibility are presented. It is shown that the intensity of the group identity of the population is determined by such factors as the degree of urbanization, education level, age, ethnicity.

Keywords: group identity, civil identity, ethnic identity, identity factors, solidarity, ethnocultural development
\end{abstract}

ДЕМИЧЕВ Илья Валерьевич - кандидат философских наук, старший научный сотрудник Центра социокультурного анализа ГАНУ Институт стратегических исследований Республики Башкортостан, (Россия, 450008, г.Уфа, ул. Кирова, 15; senmerv@таil.ru)

БАКАЕВ Руслан Султанович - научный сотрудник ГАУ Центр гуманитарных исследований Министерства культуры Республики Башкортостан (Россия, 450076, г. Уфа, ул. М. Гафури 13/1; fmd@mail.ru)

\section{ПРОБЛЕМА ЭТНИЧНОСТИ В ЦИФРОВОЙ КОММУНИКАЦИИ}

Аннотация. В статье рассматривается гипотеза о влиянии технологий сетевой коммуникации на этнические сообщества. В условиях индустриального общества, при массированном выравнивании образа жизни и акценте на профессиональных качествах стиралась грань между этническими сообществами. На данный социокультурный процесс наложилось внедрение институциональных структур нового технологического уклада, ярким примером чего является сетевые коммуникации. Следствием этого является превращение этнического компонента идентичности в компонент субкультурный, не выступающий объединительным фактором для большой общности.

Ключевые слова: сетевые коммуникации, этническая общность, дискурс, социокультурная общность, идентичность, солидарность, субкультура

$\mathrm{P}$ азвитие цифровой среды не только меняет рутинные процессы жизнедеятельности людей, ускоряя коммуникацию и взаимодействия между субъектами. Меняется сама логика коммуникации, она становится менее завязана на непосредственную близость участников и более абстрактной по своему содержанию, касаясь поддерживаемых и транслируемых в системе образов представления реальности, но не ее самой. Прежние способы удостоверения, 